\title{
Scoliosis in rats with experimentally-induced hemiparkinsonism: dependence upon striatal dopamine denervation
}

\author{
Mario Herrera-Marschitz, Hiroya Utsumi, Urban Ungerstedt
}

\begin{abstract}
Rats suffering from experimental hemiparkinsonism induced by a unilateral injection of 6-hydroxydopamine into the left area ventralis tegmenti showed a strong ipsilateral deviation and scoliosislike skeletal deformity. The rats often showed single rotatory curves affecting the thoracic and lumbar regions, although cases with multiple curves were also found. The severity of the scoliosis was closely related to a decrease in extracellular striatal dopamine measured with microdialysis and to the development of postsynaptic dopamine receptor supersensitivity, functionally evaluated with rotational behaviour elicited with apomorphine. Indeed, rats with the strongest dopamine depletion $(>95 \%)$ and the strongest rotational responses showed the sharpest spinal deviation and skeletal deformity. These findings agree with the clinical observations that scoliosis occurs in patients with Parkinson's disease and its direction is correlated with the side of the major signs and symptoms of parkinsonism.
\end{abstract}

Scoliosis, a rotatory lateral curvature of the spine, accompanied by an asymmetric deformity of the trunk, occurs more frequently in patients with Parkinson's disease ${ }^{1}$ than in the elderly population. ${ }^{2}$ Duvoisin and Marsden ${ }^{1}$ reported evidence showing that the direction of the spinal curvature correlates with the laterality of other manifestations of parkinsonism. These authors suggested that a lesion of the substantia nigra could produce ipsilateral scoliosis in humans as well as in the rat. In the rat, a unilateral injection of the neurotoxin 6-hydroxydopamine (60HDA) into the area ventralis tegmenti containing the bundle of axons leaving the mesencephalic dopamine (DA) cell bodies produces unilateral telencephalic DA deafferentation. ${ }^{3-5}$ This is followed by a postural deviation, with the head, body and tail showing a concave curve towards the lesioned side. This postural deviation can be reversed or even converted into a compulsive contralateral rotational behaviour by treating the rat with agonists stimulating DA receptors rendered supersensitive after denervation. ${ }^{6}$ These observations led to an experimental model in rats, the rotational model, ${ }^{78}$ which has been extensively used for studying parkinsonism. However, whether the postural deviation induced by this experi- mental hemiparkinsonism is accompanied by skeletal changes affecting the spine and the trunk has not yet been studied. Grimes et $a l^{9}$ reported that while the incidence of scoliosis in patients with Parkinson's disease is higher than it is in the older general population, it is not related to age, disease stage, duration of disease, levodopa treatment, or presence of dyskinesia.

We present radiographic evidence that unilateral nigrostriatal DA denervation produces scoliosis in rats, which is associated with a decrease in extracellular striatal DA, assayed in vivo with microdialysis, ${ }^{10}$ and to the total amount and intensity of contralateral rotational behaviour induced with a low dose of systemic apomorphine.

\section{Materials and methods \\ Lesions}

60HDA lesions Sprague-Dawley male rats (Alab, Stockholm, Sweden) weighing 150$170 \mathrm{~g}$ were anaesthetised with a mixture of air and halothane and placed in a Kopf stereotaxic frame. With the skull oriented according to König and Klippel atlas, " $4 \mu \mathrm{l}$ of $60 \mathrm{HDA}-\mathrm{HCl}$ $(2 \mu \mathrm{g} / \mu \mathrm{l})$ (Sigma, St Louis, Mo, USA) was injected into the area ventralis tegmenti containing the bundle of axons leaving the mesencephalic DA cell bodies (coordinates: A $2 \cdot 8, \mathrm{~L}-1 \cdot 2, \mathrm{~V}-2 \cdot 2$ ). This lesion extensively denervates the forebrain DA-innervated areas unilaterally. 125

Ibotenic acid lesions. Rats weighing 200-250g were anaesthetised and injected with $0.5 \mu \mathrm{l}$ of ibotenic acid (IBA) $(5 \mu \mathrm{g} / \mu \mathrm{l})$ (Sigma) into the caudal part of the left substantia nigra, pars reticulata (SNR) (coordinates: A 1.8, L -2.0, $\mathrm{V}-2 \cdot 6$ ). IBA produces a relatively restricted lesion mainly affecting cell bodies located in the SNR, while sparing extrinsic neural glia and axons. ${ }^{1312}$

Behavioural evaluation of the lesions-rotational behaviour. The rats were placed on a laboratory table and their spontaneous postural deviation was recorded as previously reported. ${ }^{4}$ After checking their body weight, the rats were transferred to rotometers, ${ }^{78}$ where turns to the left or right were recorded. After a stabilisation period of 30 minutes, rotational behaviour was stimulated by administering the DA D-1/D-2 receptor agonist apomorphine $(0.05 \mathrm{mg} / \mathrm{kg} \mathrm{sc})$ (Apoteksbolaget, Stockholm, Sweden). The rotational behaviour of each animal was expressed as the number of turns for the entire duration of the behaviour (total rotation) or as the maximum turns/min interval (maximum
Received 24 February 1989

and in revised form

Accepted 6 July 1989 
intensity). The apomorphine test was repeated three to four times during a period of one year following the lesion. At least one month elapsed between the apomorphine tests, the last one microdialysis experiment.

\section{In vivo microdialysis}

One year old normal (500-600g) or lesioned rats $(400-500 \mathrm{~g})$ were anaesthetised and placed in a stereotaxic frame. Two microdialysis probes (CM 10, Carnegie Medicin AB, Stockholm, Sweden) (dialysing length $=4 \mathrm{~mm}$; diameter $0.5 \mathrm{~mm}$ ) were implanted, one into the left and the other into the right striatum (coordinates: $\mathrm{B} 0 \cdot 7, \mathrm{~L} \pm 3.0, \mathrm{~V}-1.5)$. The microdialysis probes were perfused with a Ringer solution $\left(147 \mathrm{mmol} \mathrm{Na}{ }^{+}, 2.3 \mathrm{mmol}\right.$ $\mathrm{Ca}^{2+}, 4 \mathrm{mmol} \mathrm{K}^{+}$and $155.6 \mathrm{mmol} \mathrm{Cl}^{-}$, $\mathrm{pH}$ 6.0) (basal condition) and Ringer including $100 \mathrm{mM} \mathrm{KCl}$ (stimulated condition) at a constant flow of $2 \mu \mathrm{l} / \mathrm{min}$ maintained with a microdialysis pump (CMA 100, Carnegie Medicin AB). Changes in the perfusion medium were performed by using a liquid switch (CM 11, Carnegie Medicin AB), which makes it possible instantaneously to shift syringes containing the different perfusion media without introducing air into the system. tubes (Eppendorf, Hamburg, FRG), containing $10 \mu \mathrm{l}$ of $1 \mathrm{M}$ perchloric acid. Halothane anaesthesia was maintained throughout the experiment by free breathing into a mask fitted over the nose of the rat $(1 \cdot 0-1 \cdot 5 \%$ of halothane maintained by an air flow of $1.51 / \mathrm{min}$ ). Body temperature was kept at $37^{\circ} \mathrm{C}$ with a heating pad controlled via a rectal thermometer. DA and metabolites were assayed in $20 \mathrm{~min}$ fractions on a reverse phase ion-pair High Performance Liquid Chromatography (HPLC) system (BAS, West Lafayette, IN, USA) with electrochemical detection. ${ }^{14}$

\section{Radiographic evaluation}

One year old normal and lesioned rats were occurring approximately one month before the Samples $(40 \mu \mathrm{l})$ were collected in $300 \mu \mathrm{l}$ assay anaesthetised with ether and decubitus dorsal

Table 1 Contralateral rotation produced by apomorphine $0.05 \mathrm{mg} / \mathrm{kg} \mathrm{sc}$

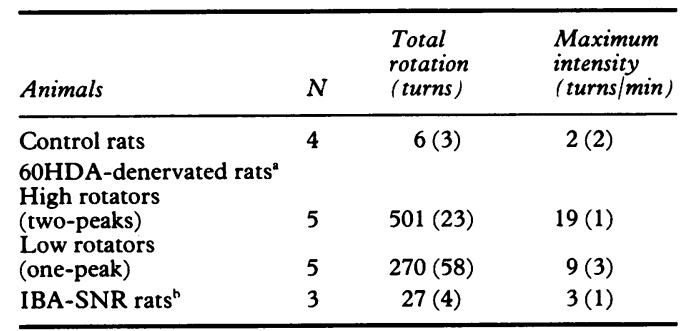

"Rats receiving one injection of $4 \mu l$ of 6-hydroxydopamine $(60 H D A)(2 \mu g / \mu l)$ into the left ventralis tegmenti area which contains the bundle of axons leaving the mesencephalic dopamine cell bodies.

Rats receiving $0.5 \mu \mathrm{l}$ of ibotenic acid (IBA) $(10 \mu \mathrm{g} / \mu \mathrm{l})$ into the caudal part of the left substantia nigra, pars reticulata (SNR). Last apomorphine test, done approximately one month previous to the time when the microdialysis experiment was performed.

and lateral radiograms were taken using a dental Roentgen apparatus. A $18 \times 24 \mathrm{~cm}$ half speed, high contrast film (Osray C, $50 \mathrm{DW}$, Agfa-Gevaert, Hamburg) was used.

\section{Statistics}

Mean values and standard errors of the means (SEM) were calculated and differences between means tested with Student's $t$ test. A level of $P<0.05$ for one tail test was considered critical for statistical significance.

\section{Results}

\section{Behavioural evaluation}

All the 60HDA denervated rats showed a postural deviation towards the lesioned side. ${ }^{518}$ This deviation could be reversed and transformed into a strong rotational behaviour if the animals were stimulated with apomorphine. A dose of $0.05 \mathrm{mg} / \mathrm{kg} \mathrm{sc}$ apomorphine produced a contralateral behaviour lasting approximately 70 minutes. On the basis of the intensity of the rotational behaviour elicited by apomorphine $0.05 \mathrm{mg} / \mathrm{kg} \mathrm{sc}$, two groups of $60 \mathrm{HDA}-$ denervated rats are described (table 1): (1) a first group producing a strong two-peak response (high rotators) and (2) a second group producing a weaker one-peak response (low Table 2 Striatal extracellular dopamine ( $D A$ ) and metabolites ( $N M$, means $S E M)$ collected in vivo by microdialysis and measured by HPLC-EC.

\begin{tabular}{|c|c|c|c|c|c|c|}
\hline Animals & $N$ & $\begin{array}{l}\text { Right striatum } \\
\text { Basal }^{a} \\
n M\end{array}$ & $\begin{array}{l}\text { Stimulated } \\
n M\end{array}$ & $\begin{array}{l}\text { Left striatum } \\
\text { Basal } \\
n M\end{array}$ & $\begin{array}{l}\text { Stimulated } \\
n M\end{array}$ & Comparisons \\
\hline $\begin{array}{l}\text { Control rats } \\
\text { DA } \\
\text { DOPAC } \\
\text { HVA } \\
\text { 5-HIAA }\end{array}$ & 4 & $\begin{array}{r}12(2) \\
1282(121) \\
792(86) \\
404(70)\end{array}$ & $\begin{array}{ll}320 & (64) \\
492 & (50) \\
443 & (48) \\
243 & (32)\end{array}$ & $\begin{array}{rr}11 & (2) \\
1173 & (119) \\
910 & (90) \\
280 & (60)\end{array}$ & $\begin{array}{ll}280 & (39) \\
544 & (66) \\
437 & (70) \\
170 & (30)\end{array}$ & $\begin{array}{l}\text { ns } \\
\text { ns } \\
\text { ns } \\
\star\end{array}$ \\
\hline $\begin{array}{l}60 \text { HDA-denervated rats } \\
\text { High rotators } \\
\text { DA } \\
\text { DOPAC } \\
\text { HVA } \\
\text { 5-HIAA }\end{array}$ & 5 & $\begin{array}{rr}9 & (2) \\
883 & (159) \\
743 & (87) \\
73 & (25)\end{array}$ & $\begin{aligned} 90 & (22) \\
285 & (26) \\
199 & (24) \\
45 & (10)\end{aligned}$ & $\begin{array}{cc}0.4 & (0.2) \\
3 \cdot 3 & (0.8) \\
8 \cdot 1 & (1.4) \\
66 & (30)\end{array}$ & $\begin{aligned} 1 \cdot 4 & (0 \cdot 6) \\
2 \cdot 1 & (0 \cdot 8) \\
4 \cdot 1 & (2 \cdot 2) \\
40 & (9)\end{aligned}$ & $\begin{array}{l}\star \star \\
\star \star \\
\star \star \\
\text { ns }\end{array}$ \\
\hline $\begin{array}{l}\text { Low rotators } \\
\text { DA } \\
\text { DOPAC } \\
\text { HVA } \\
\text { 5-HIAA }\end{array}$ & 5 & $\begin{array}{r}10(3) \\
1142(175) \\
821(105) \\
162(34)\end{array}$ & $\begin{array}{rr}138 & (29) \\
572 & (70) \\
354 & (33) \\
81 & (10)\end{array}$ & $\begin{aligned} 1 \cdot 1 & (0 \cdot 5) \\
27 & (11) \\
28 & (10) \\
127 & (35)\end{aligned}$ & $\begin{array}{cl}6 \cdot 4 & (1 \cdot 7) \\
10 & (4) \\
7 \cdot 7 & (2 \cdot 7) \\
28 & (12)\end{array}$ & $\begin{array}{l}\star \star \\
\star \star \\
\star \star \\
\star\end{array}$ \\
\hline $\begin{array}{l}\text { IBA-SNR rats } \\
\text { DA } \\
\text { DOPAC } \\
\text { HVA } \\
\text { 5-HIAA }\end{array}$ & 3 & $\begin{array}{r}12(3) \\
1139(280) \\
745(26) \\
227(150)\end{array}$ & $\begin{array}{r}793(351) \\
572(208) \\
415(20) \\
84 \quad(23)\end{array}$ & $\begin{array}{l}(0 \cdot 3) \\
(36) \\
(74) \\
(14)\end{array}$ & $\begin{aligned} 47 & (16) \\
130 & (13) \\
252 & (32) \\
189 & (19)\end{aligned}$ & $\begin{array}{l}\star \\
\star \star \\
\star \star \\
\text { ns }\end{array}$ \\
\hline
\end{tabular}

"Basal levels correspond to measurements done under Ringer perfusion (60-80 min period after the implantation of the microdialysis probes). ${ }^{b}$ Stimulated levels correspond to measurements done under Ringer $+100 \mathrm{mM}$ perfusion (220-240 min period). ${ }^{\circ}$ Comparisons between right and left striatal basal levels were tested with $t$-test. ${ }^{\star}<0.05 ; \star \star<0.01$. 

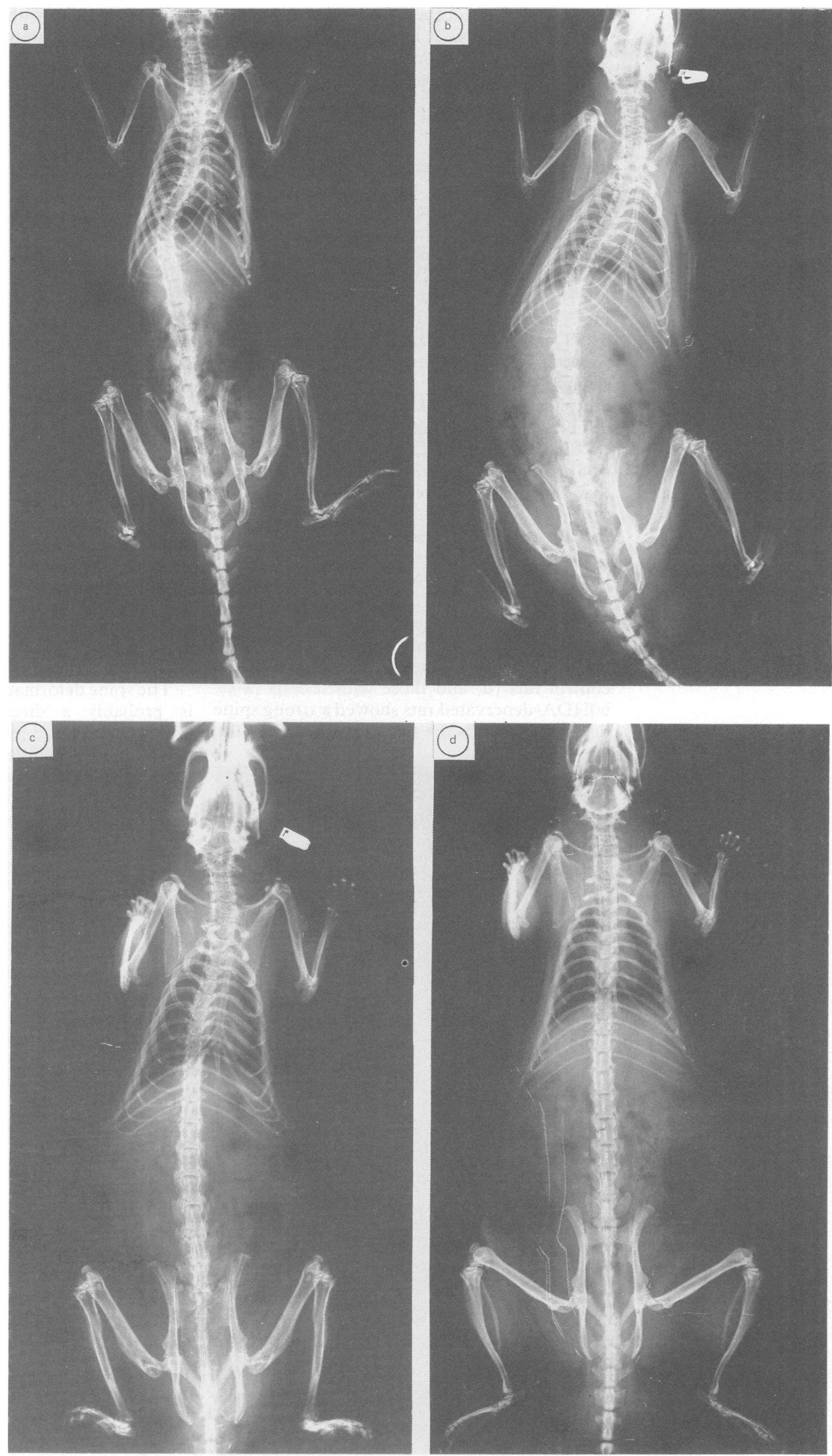

Figure 1a-d Decubitus-dorsal radiograms of unilaterally (left) lesioned (a-c) and control (normal) (d) rats. (a) $60 H D A$-lesioned rat representing the high rotator group. (b) $60 H D A$-lesioned rat representing the low rotator group. (c) rat with a unilateral IBA into the substantia nigra, pars reticulata. (d) one year old normal rat. 
rotators). ${ }^{581920}$ Neither the control rats nor those with IBA-SNR lesions showed spontaneous postural deviation or rotational behaviour following apomorphine stimulation $(0.05 \mathrm{mg} /$ $\mathrm{kg} \mathrm{sc}$ ).

\section{In vivo microdialysis}

Table 2 shows the levels of DA and metabolites found in perfusates taken by microdialysis from the right and left striatum of control and lesioned animals, under basal and stimulated conditions. The $60 \mathrm{HDA}$ lesion produced a strong reduction of DA release and levels of DA metabolites, compared with their own intact striatum or to striata of control rats. The 5-HT metabolite, 5-HIAA was less affected (table 2). The high rotator group showed the strongest inhibition (high rotators $>95 \%$ inhibition of basal DA; low rotators $>90 \%$ inhibition). The nigral IBA lesion also produced a drop in DA ( $>60 \%$ DA inhibi-. tion), which, however, was significantly lower than that observed after $60 \mathrm{HDA}$

\section{Radiographic evaluation}

Six 60HDA-denervated rats (randomly selected between the high $(\mathbf{N}=3)$ and low $(N=3)$ rotator groups), two IBA-SNR rats and two normal (aged-matched) rats were radiographically examined. Figure 1 shows decubitus dorsal radiograms taken from the control rats (d) and those with lesions $(a-c)$. $60 \mathrm{HDA}$-denervated rats showed a strong spine deviation towards the side of the lesion (fig la,

Figure 2 Lateral radiogram of a $60 \mathrm{HDA}$ lesioned rat (high rotator). The deviation of the neck compensates for the thoracic-lumbar curve ipsilateral to the lesion side. b), while animals with a IBA-lesion of the SNR (fig 1c) showed only a slight deviation also directed towards the lesioned side. The $60 \mathrm{HDA}$-denervated rats showed often single rotatory curves affecting the thoracic and lumbar regions. However, as shown in fig 2 , cases with multiple curves were also found. High rotator animals showed the sharpest spine deviation and signs of skeletal deformations (cases in fig la and 2).

\section{Discussion}

This study shows that a unilateral mesencephalic DA denervation induced by intracerebral 60HDA administration produces a chronic spine deviation towards the denervated side, which after radiographic examination, looks like the scoliosis described in Parkinson's patients. ${ }^{18}$ Most of the denervated rats showed single rotatory curves affecting the thoracic and lumbar regions, but cases with multiple curves were also found (fig 2). The main direction of the deviation was always towards the denervated side. The sharpness of the spine deviation was directly associated with the amount of striatal DA decrease measured by microdialysis (table 2) and with the degree of postsynaptic DA receptor supersensitivity, functionally evaluated with the rotational behaviour model (table 1).

The spine deformation reported in this study is probably a direct consequence of the imbalance induced by the unilateral dopamine denervation, which leads to an increase in the tone of skeletal muscles, including the paravertebral muscles. Indeed, a persistent activation of skeletal muscles seems to be the cause for the rigidity observed in Parkinson's patients. ${ }^{15}$ Rigidity can also be produced by high doses of neuroleptic drugs such as chlorpromazine and reserpine, and counteracted with DA agonists such as levodopa or apomorphine. ${ }^{1617}$

In conclusion scoliosis is found in animals with experimentally-induced hemiparkinsonism, with thoracic-lumbar curves oriented towards the lesion side. The severity of the scoliosis was directly associated with a decrease in striatal DA. This spine deformation can be considered to be similar to that found in Parkinson's patients. ${ }^{1}$ We suggest that a timed radiographic screening of this sort of deformation may be valuable for differential diagnosis of early signs of parkinsonism from other neuromotor disorders. The scoliosis associated with unilateral dopamine denervation can probably be attenuated or perhaps prevented by physiotherapy. However, when a severe spine deformation is established, it is unlikely to be reversed by levodopa or transplantation therapy.

This study was supported by grants from the Swedish Medical Research Council (21P 08154; 14X-08669), Karolinska institutet fonder, The Swedish Medical Society, Loo och hans Ostermans fond, Carnegie Medicin AB. We thank Ms Lotta Larsen-Erdélyi and Ms Monica Karlsson for their excellent assistance. 
1 Duvoisin RC, Marsden CD. Note on the scoliosis of Parkinsonism. J Neurol Neurosurg Psychiatry 1975; 38:787-93.

2 Robin GC, Span Y, Steinberg R, Makin M, Menczel J. Scoliosis in the elderly. A follow-up study. Spine 1982;7:355-9.

3 Ungerstedt $U$. Stereotaxic mapping of the monoamine pathways in the rat brain. Acta Physiol Scand 1971;Suppl path:1-48.

4 Ungerstedt U. Striatal dopamine release after amphetamine or nerve degeneration revealed by rotational behaviour. or nerve degeneration revealed by rotation
Acta Physiol Scand 1971;Suppl 357:49-68.

5 Herrera-Marschitz M. Neuropharmacology and functional anatomy of the basal ganglia. Stockholm: Karolinska institutet-Thesis, 1986

6 Ungerstedt U. Postsynaptic supersensitivity after 6hydroxydopamine induced degeneration of the nigrostriatal dopamine system. Acta Physiol Scand 1971;Suppl 367:69-93.

7 Ungerstedt U, Arbuthnott GW. Quantitative recording of rotational behaviour in rats after 6-hydroxydopamine lesions of the nigrostriatal dopamine system. Brain Res 1970;24:485-93.

8 Herrera-Marschitz $M$, Ungerstedt U. Evidence that striatal efferents relate to different dopamine receptors, Brain Res 1984;323:269-78.

9 Grimes JD, Hassan MN, Trent G, Halle D, Armstrong GWD. Clinical and radiographic features of scoliosis in Parkinson's disease. Advances in Neurology 1986;45: 353-5.

10 Ungerstedt U, Herrera-Marschitz M, Jungnelius U, Ståhle L, Tossman U, Zetterström $T$. Dopamine synaptic mechanisms reflected in studies combining behavioural recording and brain dialysis. Advances in the Biosciences 1982;27:219-31.

11 König JFR, Klippel RA. The rat brain. A stereotaxic atlas of the forebrain and lower parts of the brain stem. Hamburg: $\mathbf{R}$
E Krieger 1963.

12 Christensson-Nylander I, Herrera-Marschitz $M$, Staines $W$, et al. Striato-nigral dynorphin and substance $P$ pathways in the rat. I. Biochemical and immunohistochemical studies. Exp Brain Res 1986;64:169-92.

13 Schwarcz R, Hökfelt T, Fuxe K, Jonsson G, Goldstein M, Terenius $L$. Ibotenic acid-induced neuronal degeneration: a morphological and neurochemical study. Exp Brain Res 1979;37:199-216.

14 Herrera-Marschitz M, Goiny M, Utsumi H, Ungerstedt U. Mesencephalic dopamine innervation of the frontoparietal (sensorimotor) cortex of the rat: a microdialysis study. Neuroscience Lett 1989;97:266-70.

15 Andrews CJ, Burke D, Lance JW. The response to muscle stretch and shortening in Parkinsonian rigidity. Brain 1972;95:795-812.

16 Andén N-E, Johnels B. Effect of local application of apomorphine to the corpus striatum and to the nucleus accumbens on the reserpine-induced rigidity in rats. Brain Res 1983;133:386-9.

17 Johnels B. Reserpine-induced rigidity in rats drug effects on muscle tone from corpus striatum and nucleus accumbens. Pharmacol Biochem Behav 1983;19:463-70.

18 Ungerstedt $U$, Herrera-Marschitz $M$. Behavioural pharmacology of dopamine receptor mechanisms. In: L Stjärne, P Hedqvist, $\mathrm{H}$ Lagercrantz, $\AA$ Wennmalm (eds). Chemical Neurotransmission: 75 years. New York, Academic Press, 1981;481-94.

19 Herrera-Marschitz $M$, Ungerstedt U. Evidence that apomorphine and pergolide induce rotation in rats by apomorphine and pergolide induce rotation in rats by
different actions on D1 and D2 receptor sites. Eur $J$ Pharmacol 1984;98:165-76.

20 Herrera-Marschitz M, Forster C, Ungerstedt U. Rotational behaviour elicited by intracerebral injections of apomorphine and pergolide in 6-hydroxy-dopamine-lesioned rats. I: comparison between systemic and intrastriatal injections. Acta Physiol Scand 1985;125:519-27. 